\title{
Sol-gel as methodology to obtain bioactive materials
}

\author{
THIAGO J. RIBEIRO, OMAR J. DE LIMA, EMERSON H. FARIA, LUCAS A. ROCHA, \\ PAULO S. CALEFI, KATIA J. CIUFFI and EDUARDO J. NASSAR \\ Departamento de Química, Universidade de Franca, Av. Dr. Armando Salles Oliveira, 201, \\ Pq. Universitário, 14404-600 Franca, SP, Brasil
}

Manuscript received on July 2, 2012; accepted for publication on June 4, 2013

\begin{abstract}
We employed the sol-gel methodology to obtain a silica matrix modified with calcium and phosphate ions. We prepared the matrix by hydrolysis and condensation of the precursors triethyl phosphate, calcium nitrate, and tetraethylorthosilicate, which were the sources of phosphate, calcium, and silicon, respectively. We dried and heat-treated the samples at 110 or $900^{\circ} \mathrm{C}$ and placed them in simulated body fluid (SBF) for three days. We conducted scanning electron microscopy, X-ray diffraction, and infrared spectroscopy analyses, which evidenced that the sample treated at $110^{\circ} \mathrm{C}$ contained calcium phosphate silicate and hydroxyapatite before and after contact with $\mathrm{SBF}$, respectively. The sample treated at $900^{\circ} \mathrm{C}$ exhibited a hydroxyapatite phase before and after contact with SBF, but the crystalline phase was more evident after the contact. In conclusion, the sol-gel methodology provided bioactive samples for bone regeneration.
\end{abstract}

Key words: biomaterials, bioactive, SBF, sol-gel methodology.

\section{INTRODUCTION}

Over the last 20 years, the term hybrid has been used to designate materials with organic-inorganic or bioinorganic characteristics. These materials present new properties and have a multifunctional nature, allowing for novel applications in various fields (Sanchez et al. 2011). In general, organic-inorganic hybrid materials are defined as materials with both organic and inorganic components; therefore, bioceramics cannot be classified as such. However, due to its bioactivity and the interaction established between its inorganic components and the organic constituents in the human body, bioceramics is also considered to be hybrid, which has led to its use in bone regeneration (Vallet-Regí et al. 2011).

Correspondence to: Eduardo José Nassar

E-mail: ejnassar@unifran.br
Hydroxyapatite (HA) is bioceramic consisting of calcium and phosphate ions; it has the formula $\mathrm{Ca}_{10}\left(\mathrm{PO}_{4}\right)_{6}(\mathrm{OH})_{2}$. The chemical and biological features of HA have enabled its application in bone and dental tissue restoration (Santos et al. 2005, Kawachi et al. 2000). HA exhibits a bioactive characteristic; i.e., it can interact with surrounding tissue after implant (Liu et al. 2002). This material is useful in several applications, including its use as drug delivery system (Iafisco et al. 2012, Salimi et al. 2012, Chen et al. 2011, Zamoume et al. 2011). Recent articles have drawn attention to the application of calcium phosphate as bone substituent, especially in the HA and tricalcium phosphate form (Bose and Tarafder 2012, Tofighi 2012, Alonso et al. 2012, Kim and Jeon 2012, Hong et al. 2011), mainly in the area of dentistry (Catel et al. 2012, Tirapelli et al. 2010). 
Various methodologies have been employed to synthesize HA. Depending on the selected technique - mechanochemical method (Tabrizi et al. 2009), combustion (Ghosh et al. 2011), others (Rodriquez-Clemente et al. 1998, Yoshmura et al. 1994, Lim et al. 1999) crystals of different morphology, size, and shape can arise. The sol-gel process is attractive because it uses mild conditions and easily available precursors. Countless literature works have reported the use of this route to prepare calcium-based compounds with applications in biomaterials (Radev et al. 2012, Wei et al. 2011, Heinemann et al. 2011, Jadalannagari et al. 2011, Bandeira et al. 2011, Chatzistavrou et al. 2011, Arcos and Vallet-Regí 2010).

In this study, we used the sol-gel methodology to obtain a silica matrix modified with calcium and phosphate ions. We dried the resulting sample at $50^{\circ} \mathrm{C}$ and treated it at either 110 or $900^{\circ} \mathrm{C}$. To find out whether the synthesized materials were bioactive, we immersed them into simulated body fluid (SBF) for three days. We characterized the samples by thermal analysis (TG/DTA), X-ray diffraction (XRD), infrared spectroscopy (FTIR), and scanning electron microscopy (SEM).

\section{MATERIALS AND METHODS}

\section{SOL PREPARATION}

The Si-Ca-P sol solution was prepared from the precursors triethylphosphate (TEP), calcium nitrate $\left(\mathrm{Ca}\left(\mathrm{NO}_{3}\right)_{2}\right)$, and tetraethylortosilicate (TEOS). Briefly, $0.03 \mathrm{~mol}$ of TEP were dissolved in distilled water for $24 \mathrm{~h}$, followed by addition of $0.05 \mathrm{~mol}$ of $\mathrm{Ca}\left(\mathrm{NO}_{3}\right)_{2}$ and stirring for an additional $24 \mathrm{~h}$. Then, $0.05 \mathrm{~mol}$ of TEOS in ethanol solution was added, and the mixture was maintained under stirring until gel formation ( $\sim 1$ week), at room temperature. The samples treated at 110 and $900^{\circ} \mathrm{C}$ were placed in contact with simulated body fluid (SBF) for three days. After this period, the samples were centrifuged, washed, dried, and characterized by TG/DTA, XRD, FTIR, and SEM analyses. The solid sample was designated as HAS.

SiMULATED Body Fluid (SBF)

The SBF aqueous solution was prepared as described in literature (Kokubo 1991); the salt concentrations were: $\mathrm{NaOH} 200 \mathrm{mmol} \mathrm{L}^{-1}, \mathrm{NaHCO}_{3} 4 \mathrm{mmol} \mathrm{L}^{-1}, \mathrm{KCl}$ $3 \mathrm{mmol} \mathrm{L}-1, \mathrm{Na}_{2} \mathrm{HPO}_{4} 2 \mathrm{mmol} \mathrm{L}-1, \mathrm{MgCl}_{2} 3 \mathrm{mmol}$ $\mathrm{L}^{-1}, \mathrm{NaSO}_{4} 0.6 \mathrm{mmol} \mathrm{L}^{-1}$, and tris(hydroxymethyl)aminomethane $80 \mathrm{mmol} \mathrm{L}^{-1}$.

THERMAL ANALYSIS (TG/DTA)

The thermal analysis (TG/DTA) was carried out in a thermal analyzer TA - Instruments - SDT Q600 - Simultaneous DTA-TG, in nitrogen atmosphere, at a heating rate of $20^{\circ} \mathrm{C} \cdot \mathrm{min}^{-1}$, from 25 to $1500^{\circ} \mathrm{C}$.

X-RAY DIFFRACTION (XRD)

The X-ray diffractograms were recorded at room temperature on a diffractometer Rigaku Geigerflex $\mathrm{D} / \mathrm{Max}-\mathrm{c}$ equipped with a $\mathrm{CuK} \alpha$ radiation monochromator $(\lambda=1.5405 \AA)$. The diffractograms were registered with $2 \theta$ values ranging from 5 to $75^{\circ}$, at a resolution of $0.05^{\circ}$.

\section{FOURIER-TRANSFORM INFRARED (FTIR) SPECTROSCOPY}

The FTIR spectra were recorded on a Shimadzu model IR PRESTIGE 21 spectrophotometer with Fourier transform, using the $\mathrm{KBr}$ pellet technique and a sample/KBr ratio of 1:300. The spectra were measured over the $4000-400 \mathrm{~cm}^{-1}$ region with a $1 \mathrm{~cm}^{-1}$ resolution. Each spectrum was scanned over 1000 times, to increase the signal-to-noise ratio.

SCANNING ELECTRON MiCROSCOPY (SEM) AND ENERGY

DISPERSIVE X-RAY SPECTROSCOPY (EDS)

The samples were fixed on microscopic support and coated with a thin gold layer on SCD 050 SputterCoater, BAL Tec ${ }^{\circledR}$, using a sputtering method. SEM and EDS images were registered on a Carl Zeiss Model EVO 50 Cambridge (UK) microscope. 


\section{RESULTS AND DISCUSSION}

THERMAL ANALYSIS (TG/DTA)

Figure 1 depicts the TG, DTG, and DTA curves for the sample dried at $50^{\circ} \mathrm{C}$, HAS, which displayed the following mass loss steps: between 26 and $128^{\circ} \mathrm{C}$, ascribed to water molecules produced by hydrolysis of the precursors and the solvent (ethanol) employed during the synthesis; between 128 and $262^{\circ} \mathrm{C}$, attributed to decomposition of the ethyl groups present in the precursors TEOS and TEP; from 262 to $465^{\circ} \mathrm{C}$, due to residual organic product from the decomposition of the precursors; and from 445 to $604^{\circ} \mathrm{C}$, assigned to the dehydroxylation of the silanol groups (Si-OH), which gives rise to the inorganic polymer (Si-O-Si) (Bandeira et al. 2011).

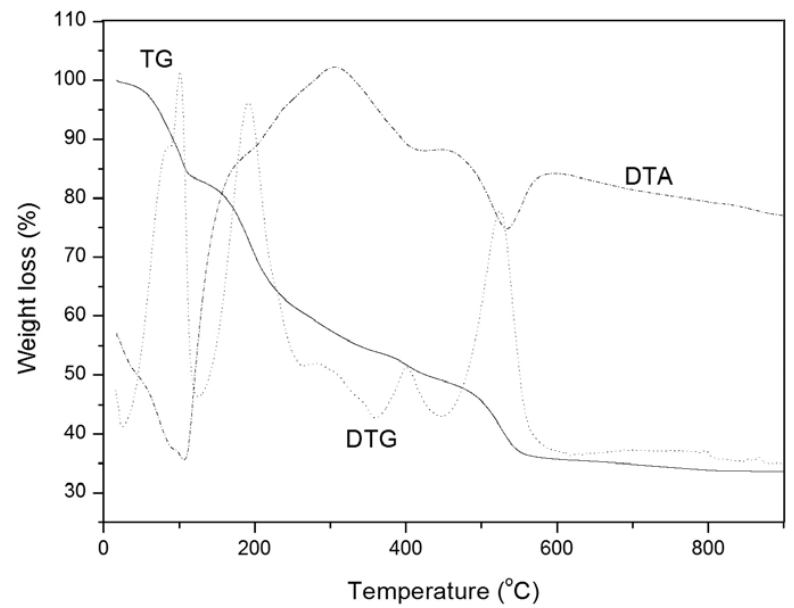

Figure 1 - Location of the study area on Areuá Island, Curuçá, State of Pará, Brazilian Amazon.

The HAS samples placed in contact with SBF and submitted to heat-treatment at 110 and $900^{\circ} \mathrm{C}$ displayed three mass loss stages. Table I lists the temperature ranges and the corresponding percent weight loss of these samples; Figures $2 \mathrm{a}$ and $\mathrm{b}$ illustrate their TG, DTG, and DTA curves.

Both heat-treated samples exhibited similar weight loss regions; the main difference lay on the percent weight loss. The first stage, with mass percent loss of approximately $7.5 \%$ for both samples, can be attributed to adsorbed water. The second step involved
TABLE I

Temperature range and corresponding \% weight loss for the samples HAS treated at 110 and $900^{\circ} \mathrm{C}$ after contact with SBF for three days.

\begin{tabular}{ccc}
\hline Sample & $\begin{array}{c}\text { Temperature } \\
\text { range }\left({ }^{\circ} \mathrm{C}\right)\end{array}$ & $\begin{array}{c}\text { Weight loss } \\
(\%)\end{array}$ \\
\hline HAS treated $110^{\circ} \mathrm{C}$ & $36.6-128.8$ & 7.4 \\
HAS treated $110^{\circ} \mathrm{C}$ & $150.8-596.1$ & 29.7 \\
HAS treated $110^{\circ} \mathrm{C}$ & $758.6-1072.6$ & 28.2 \\
HAS treated at $900^{\circ} \mathrm{C}$ & $29.1-140.2$ & 7.9 \\
HAS treated at $900^{\circ} \mathrm{C}$ & $174.6-497.8$ & 7.4 \\
HAS treated at $900^{\circ} \mathrm{C}$ & $728.8-1070.1$ & 11.6 \\
\hline
\end{tabular}
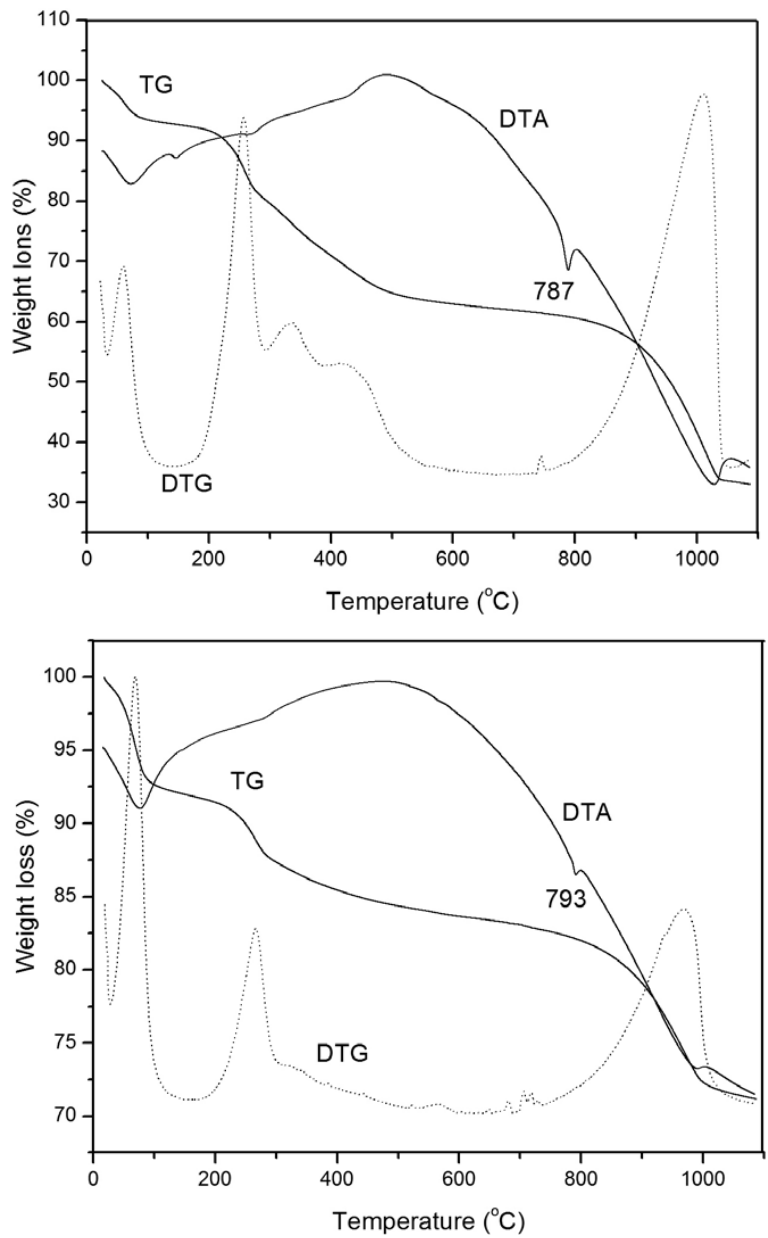

Figure 2 - TG, DTG and DTA curves for HAS treated at (a) $110^{\circ} \mathrm{C}$ or (b) $900^{\circ} \mathrm{C}$ after contact with SBF for three days.

$29.7 \%$ and $7.4 \%$ mass loss for the samples treated at 110 and $900^{\circ} \mathrm{C}$, respectively, and can be ascribed to the residual products of the synthesis and to the dehydroxylation of silanol groups. The last weight 
loss stage took place in the same region for both samples and can be assigned to HA decomposition, according to equation 1 (Trommer et al. 2007).

$\mathrm{Ca}_{10}\left(\mathrm{PO}_{4}\right)_{6}(\mathrm{OH})_{2} \rightarrow 3 \mathrm{Ca}\left(\mathrm{PO}_{4}\right)_{2}+\mathrm{CaO}+\mathrm{H}_{2} \mathrm{O}$ (equation 1)

After contact with SBF, the differential thermal analysis (DTA) revealed endothermic peaks at 787 and $792^{\circ} \mathrm{C}$ for the samples treated at 110 and $900^{\circ} \mathrm{C}$, respectively. This peak can be related to phase transition or HA decomposition.

\section{X-RAY DIFFRACTION (XRD)}

Figures $3 \mathrm{a}, \mathrm{b}$, and $\mathrm{c}$ depict the XRD of the initial sample HAS, and of the material treated at 110 or $900^{\circ} \mathrm{C}$, respectively.

HAS, dried at $50^{\circ} \mathrm{C}$ (Figure 3a), displayed two halos centered at $2 \theta=20$ and $40^{\circ}$, which indicate the presence of amorphous materials due to the silica matrix. The XRD patterns of HAS treated at 110 and $900^{\circ} \mathrm{C}$ (Figures $3 \mathrm{~b}$ and $\mathrm{c}$ ) exhibited the characteristic amorphous silica halos as well as peaks corresponding to the onset of crystallization. HAS treated at $110^{\circ} \mathrm{C}$ presented main peaks at $2 \theta=9,22,24,25,28,33$, and $40^{\circ}$, which refer to different phases containing the elements $\mathrm{Ca}, \mathrm{P}$, and $\mathrm{Si}$ and agree with card 1-471 for $\mathrm{Ca}\left(\mathrm{H}_{2} \mathrm{PO}_{4}\right) \cdot \mathrm{xH}_{2} \mathrm{O}$, card 3-319 for $\mathrm{SiP}_{2} \mathrm{O}_{7}$, and card 3-335 for $\mathrm{Ca}\left(\mathrm{PO}_{3}\right)_{2} \cdot \mathrm{XH}_{2} \mathrm{O}$. Hence, these phases and others can exist in this sample. HAS treated at $900^{\circ} \mathrm{C}$ contained peaks relative to HA (card 74-566), and peaks probably relative to other forms of calcium phosphate. The HA card is given in Figure 4.

Figures $5 \mathrm{a}$ and $\mathrm{b}$ represent the XRD for HAS treated at 110 and $900^{\circ} \mathrm{C}$, respectively, after contact with SBF for three days.

The two samples had similar XRD profiles, with peak at $2 \theta=25^{\circ}$ as well as two groups of peaks, namely in the $2 \theta$ region between 30 and $35^{\circ}$ and 45 and $55^{\circ}$. The cards 3-747 and 19-272, which correspond to $\mathrm{HA}\left(\mathrm{Ca}_{10}\left(\mathrm{PO}_{4}\right)_{6}(\mathrm{OH})_{2}\right)$ and carbonateapatite $\left(\mathrm{Ca}_{10}\left(\mathrm{PO}_{4}\right)_{3}\left(\mathrm{CO}_{3}\right)_{3}(\mathrm{OH})_{2}\right)$, respectively, also present these groups of peaks. For the sample treated at
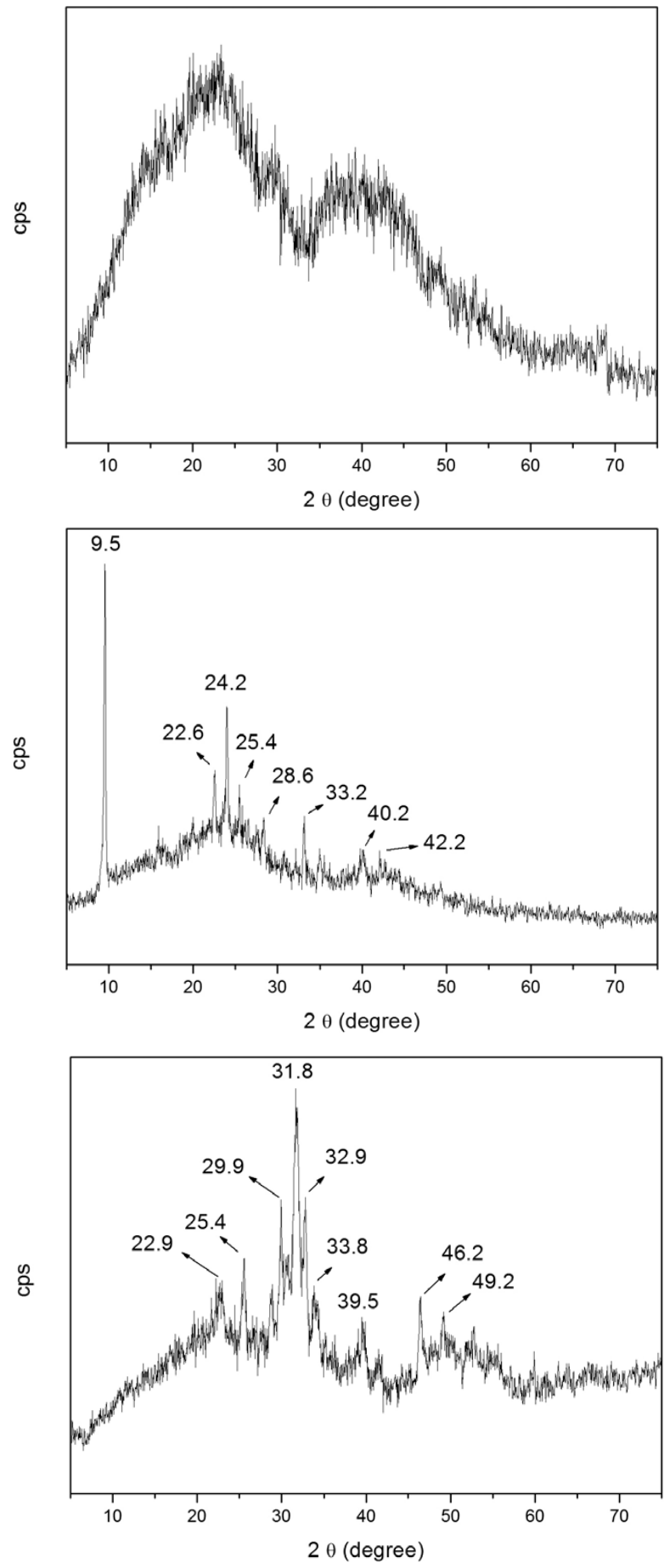

Figure 3 - XRD of the sample $\mathrm{HAS}$ dried at $50^{\circ} \mathrm{C}$ (a), treated at $110^{\circ} \mathrm{C} \mathrm{(b)} \mathrm{and} \mathrm{treated} \mathrm{at} 900^{\circ} \mathrm{C}(\mathrm{c})$.

$110^{\circ} \mathrm{C}$, the wide peaks were probably due to the poor crystallinity of the material, but we did not detect these peaks before contact of this sample with SBF. The 


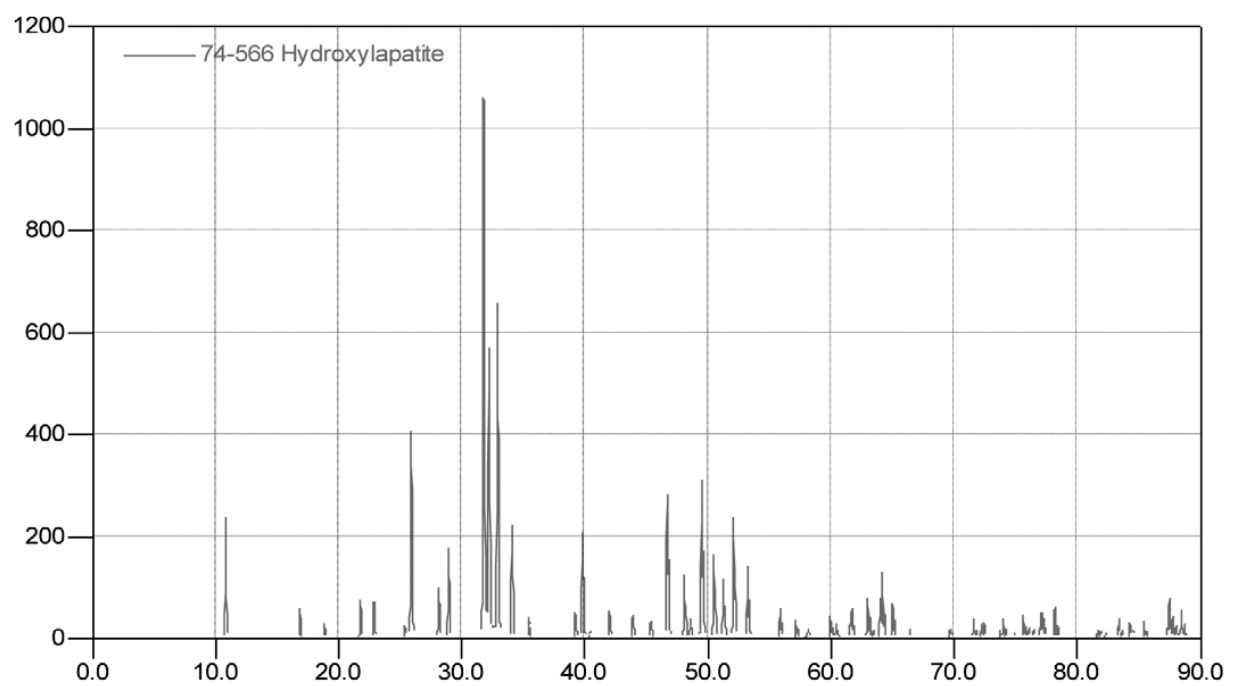

Figure 4 - Card 74-566 corresponding to the XRD of hydroxyapatite.
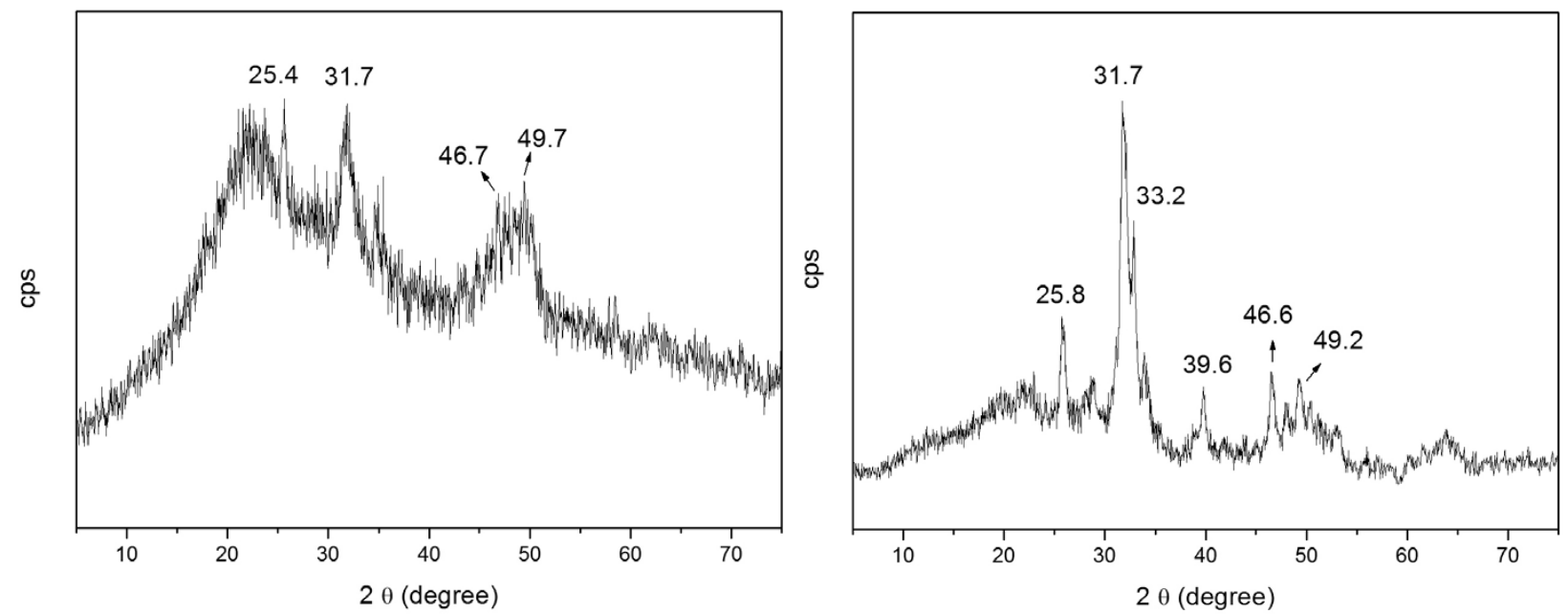

Figure 5 - XRD for the samples treated at (a) $110^{\circ} \mathrm{C}$ or (b) $900^{\circ} \mathrm{C}$ after contact with SBF for three days.

sample treated at $900^{\circ} \mathrm{C}$ already presented HA before contact with SBF, but the XRD in Figure 5 b evidenced increased crystallinity after contact. As previously discussed, the EDS analysis confirmed the presence of the $\mathrm{Ca}, \mathrm{P}, \mathrm{O}$, and $\mathrm{Si}$ elements in both samples. The characteristic halo in the $2 \theta$ region from 15 to $35^{\circ}$ in the XRD corresponded to amorphous silica matrix.

\section{FOURIER-TRANSFORM INFRARED (FTIR) SPECTROSCOPY}

Figures $6 \mathrm{a}$ and $\mathrm{b}$ show the FTIR spectra of HAS dried at $50^{\circ} \mathrm{C}$ and treated at 110 or $900^{\circ} \mathrm{C}$, before and after contact with SBF.
In Figure $6 \mathrm{a}$, the large band in the $3400 \mathrm{~cm}^{-1}$ region can be attributed to $\mathrm{OH}$ and $\mathrm{H}_{2} \mathrm{O}$ stretching. The intense band verified for the sample treated at $110^{\circ} \mathrm{C}$ suggests the presence of a major quantity of $\mathrm{OH}$ groups, which can be ascribed to incomplete condensation of the alkoxide precursors during the formation of the inorganic chain Si-O-Si. Dehydroxylation processes take place at temperatures above $400^{\circ} \mathrm{C}$, as previously observed by thermal analysis. The water molecules existing in the sample appear mainly as crystallization water present in the calcium phosphate. Indeed, XRD identified phosphate phases, as discussed above. 

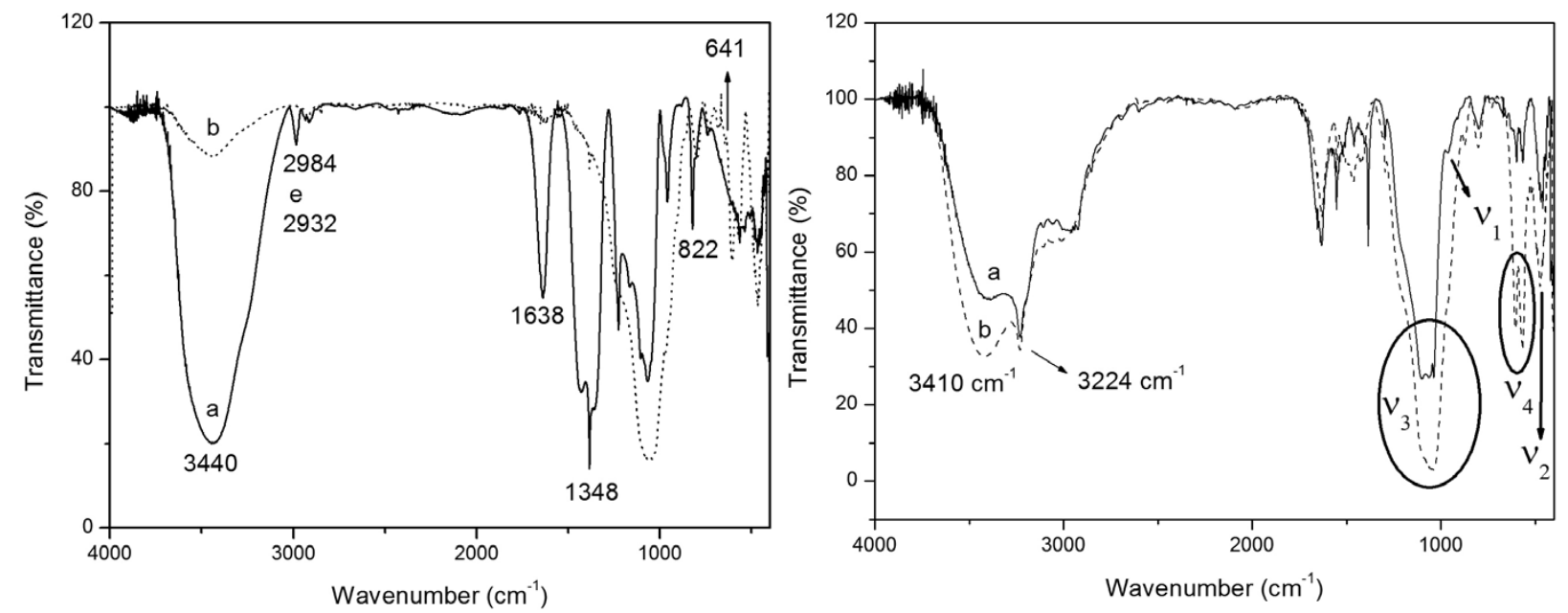

Figure 6 - FTIR of the samples HAS dried at $50^{\circ} \mathrm{C}$ and treated at (a) $110^{\circ} \mathrm{C}$ and (b) $900^{\circ} \mathrm{C}(\mathbf{A})$, and after contact with $\mathrm{SBF}$ for three days, (a) $110^{\circ} \mathrm{C}$ and (b) $900^{\circ} \mathrm{C}$ (B).

In the case of HAS treated at $900^{\circ} \mathrm{C}$, the vibration modes at 3440 and $641 \mathrm{~cm}^{-1}$ can be assigned to $\mathrm{OH}$ groups present in hydroxyapapatite (with molecular formulae $\mathrm{Ca}_{10}\left(\mathrm{PO}_{4}\right)_{6}(\mathrm{OH})_{2}$ ) (Park et al. 1998). The bands at 2984, 2932, and $1430 \mathrm{~cm}^{-1}$ correspond to $\mathrm{C}-\mathrm{H}$ bonds of organic groups present in the solvent and precursors for $\mathrm{HAS}$ treated at $110^{\circ} \mathrm{C}$, and to $\mathrm{N}-\mathrm{O}$ bond stretching of $\mathrm{Ca}\left(\mathrm{NO}_{3}\right)_{2}$ in the case of HAS treated at $900^{\circ} \mathrm{C}$. The $\mathrm{CO}_{3}{ }^{2-}$ occurring in the sample treated at $110^{\circ} \mathrm{C}$ can be identified by the bands at 1638 and 822 $\mathrm{cm}^{-1}$ (Ghosh et al. 2011). The sample treated at $110^{\circ} \mathrm{C}$ displayed vibration modes between 1200 and 1100 $\mathrm{cm}^{-1}$, which refer to the precursor $\mathrm{Si}\left(\mathrm{OCH}_{2} \mathrm{CH}_{3}\right)_{4}$. This indicates that part of the precursor did not react at this temperature. The phosphate groups exhibited vibration modes at 1348, 1226, 1062, and $960 \mathrm{~cm}^{-1}$ (Guan et al. 2005), corroborating the presence of phosphates previously evidenced by XRD.

As for Figure $6 \mathrm{~b}$, the free $\mathrm{PO}_{4}{ }^{3-}$ ion presented tetrahedral symmetry in aqueous solution, and the corresponding vibration modes appeared at $938 \mathrm{~cm}^{-1}$ $\left(v_{1}\right), 420 \mathrm{~cm}^{-1}\left(v_{2}\right), 1017 \mathrm{~cm}^{-1}\left(v_{3}\right)$, and $567 \mathrm{~cm}^{-1}$ $\left(v_{4}\right) . v_{1}$ relates to the non-degenerate stretching $\mathrm{P}-\mathrm{O}, v_{2}$ refers to the doubly degenerate bending, and $v_{3}$ and $v_{4}$ correspond to the triply degenerate stretching (Park et al. 1998). When crystallized in the apatite form, the $\mathrm{PO}_{4}{ }^{3-}$ ion can be distorted, and these bands are indeed displaced in the FTIR spectra of the samples after contact with SBF. In Figure 6, the non-degenerate band appeared as a shoulder at $959 \mathrm{~cm}^{-1}$, and its low intensity can be attributed to a large and intense adjacent band. The wide band centered at $470 \mathrm{~cm}^{-1}$ can be ascribed to the doubly degenerate modes of asymmetric O-P-O. The stronger band between 1117 and 1038 $\mathrm{cm}^{-1}$ can be assigned to two components, namely asymmetric $v_{3}$ and Si-O-Si stretching of the silica matrix. The bands at 603 and $562 \mathrm{~cm}^{-1}$ relate to the triply degenerate O-P-O modes. The stronger band at $3410 \mathrm{~cm}^{-1}$ refer to the stretching of water and/or $\mathrm{OH}$ from $\mathrm{HA}$ and the silanol groups present in the silica matrix (Park et al. 1998). The stretching at $3224 \mathrm{~cm}^{-1}$ can be ascribed to $-\mathrm{C}=\mathrm{O}$ of the carbonate apatite (Mohamed et al. 2011).

SCANNING ELECTRON MICROSCOPY (SEM) AND ENERGY DisPERSIVE X-RAY SPECTROSCOPY (EDS)

Figure 7 brings the SEM images obtained for HAS treated at $110^{\circ} \mathrm{C}$.

The sample displayed particles larger than 20 $\mu \mathrm{m}$ as well as undefined shape, and the particles presented cracks (Figure 7a). We used the region indicated in Figure 7a for the EDS analysis. We were able to detect the elements $\mathrm{Ca}, \mathrm{P}, \mathrm{Si}, \mathrm{O}$, and $\mathrm{C}$ 

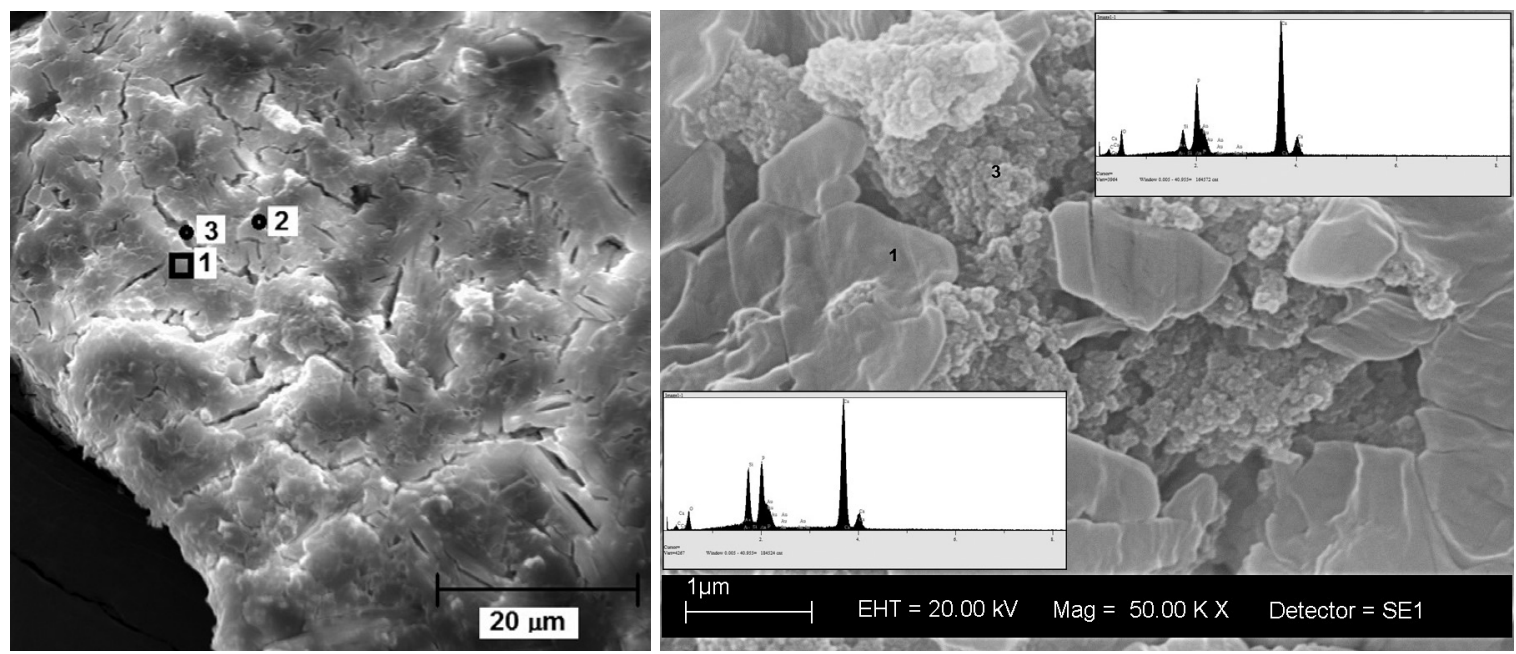

Figure 7 - SEM micrograph for HAS treated at $110^{\circ} \mathrm{C}$.

all over the region, confirming the XRD and FTIR analyses. Figure $7 \mathrm{~b}$ corresponds to enlargement of region 3 and shows different morphologies for the sample, suggesting the formation of two distinct phases. Region 3 (circle) in Figure $7 \mathrm{~b}$ revealed aggregate particles, and the EDS analysis demonstrated the major presence of the elements $\mathrm{Ca}$ and $\mathrm{P}$ in this region, as compared to region 1 (square). This indicates that calcium phosphate and silica phases arose independently.

The sample treated at $900^{\circ} \mathrm{C}$ also displayed large particles and irregular shape, but the morphology attested to better homogeneity. Figures $8 \mathrm{a}$ and $\mathrm{b}$ correspond to the SEM micrographs for HAS treated at $900^{\circ} \mathrm{C}$. In Figure $8 \mathrm{a}$, regions 1 and 2 show where the EDS analysis was accomplished and where $\mathrm{Ca}, \mathrm{P}, \mathrm{O}$, and $\mathrm{Si}$ elements were detected. The EDS evidenced different $\mathrm{Ca} / \mathrm{P}$ molar for the sample treated at $900^{\circ} \mathrm{C}$, suggesting loss of phosphate ions. More specifically, the $\mathrm{Ca} / \mathrm{P}$ ratio was $5: 1$ and $3: 1$ in regions 1 and 2, respectively. The EDS analysis performed for the sample treated at $110^{\circ} \mathrm{C}$ furnished a $\mathrm{Ca} / \mathrm{P}$ molar ratio of 1:8.
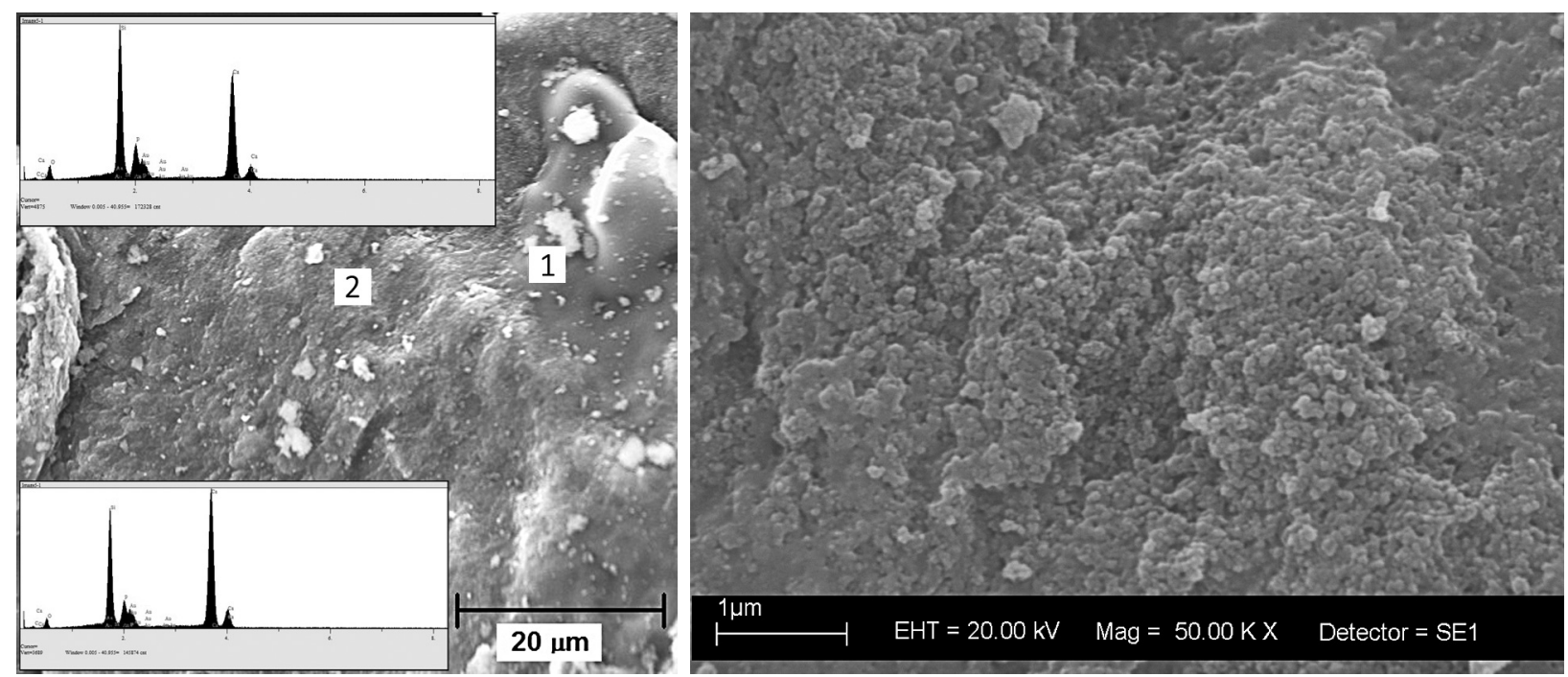

Figure 8 - SEM micrographs for HAS treated at $900^{\circ} \mathrm{C}$. 
The samples treated at 110 and $900^{\circ} \mathrm{C}$ were placed in contact with $\mathrm{SBF}$ for three days, centrifuged, washed, dried at $50^{\circ} \mathrm{C}$ for $24 \mathrm{~h}$, and characterized by TG/DTA, XRD, FTIR, and SEM analyses.

The samples treated at 110 and $900^{\circ} \mathrm{C}$ and placed in contact with SBF for three days displayed different morphologies, as seen in Figure 9.
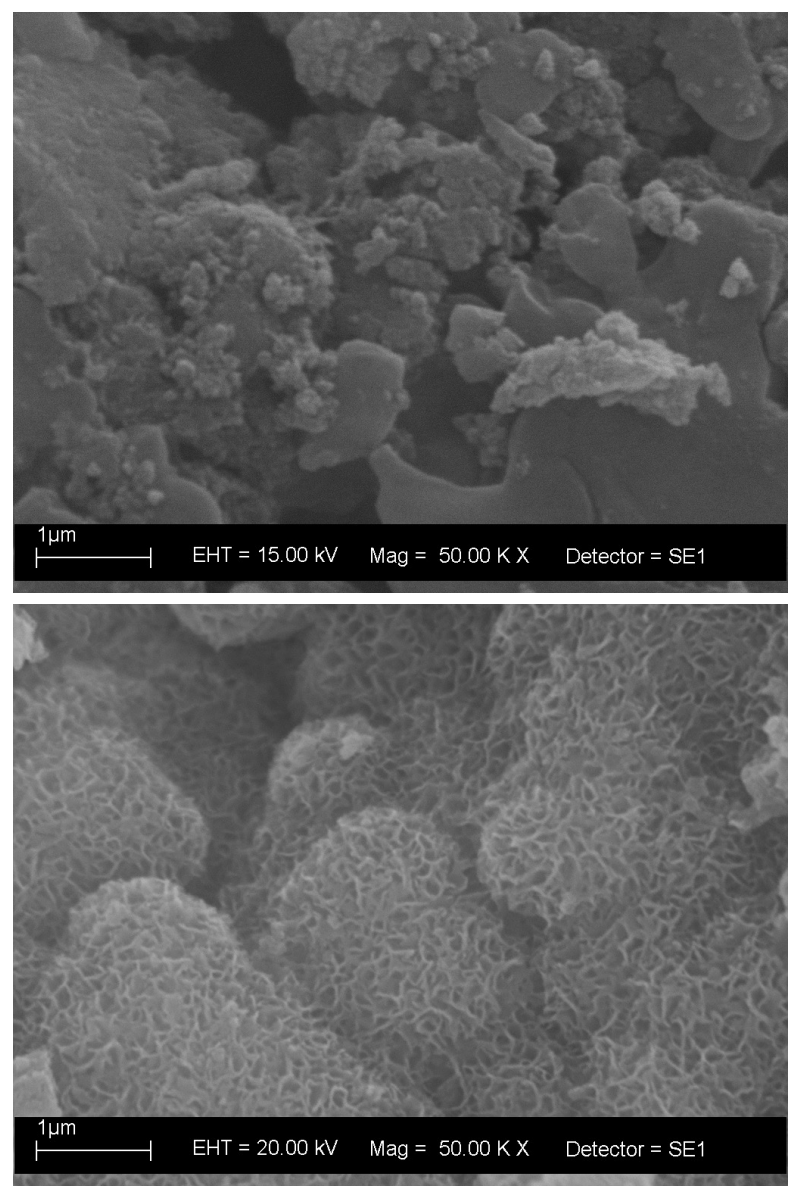

Figure 9 - SEM micrographs of the samples treated at (a) $110^{\circ} \mathrm{C}$ or (b) $900^{\circ} \mathrm{C}$ after contact with SBF for three days.

Figure 9 evidenced two kinds of particles for the materials, namely agglomerate and plates, as verified for the samples before contact with SBF (Figure 7). However, the agglomerate appeared in major quantity after contact with SBF, indicating formation of a new phase, probably HA, as revealed by the XRD and FTIR analyses. HAS treated at $900^{\circ} \mathrm{C}$ exhibited distinct morphologies before and after contact with SBF. Figure $9 \mathrm{~b}$ attested to the formation of particles on the surface of the sample. Zhou et al. (Zhou et al. 2008) also detected the same structure, and the present findings corroborate the XRD and FTIR data analyses. The EDS analysis indicated the presence of the elements $\mathrm{Ca}, \mathrm{P}, \mathrm{Si}$, and $\mathrm{O}$.

\section{CONCLUSION}

The sol-gel methodology is a chemical process that allows for the synthesis of biomaterials. The characterization studies accomplished here showed the presence of the inorganic components of the bone, carbonate and hydroxyapatite, in the synthesized samples after contact with SBF, indicating that the materials produced by this methodology act as osteoinductor. The low temperature required by the sol-gel method opens the perspective of obtaining biomaterials as bone substituent. Our findings are also important for drug incorporation into the samples, which can be used as drug delivery systems.

\section{ACKNOWLEDGMENTS}

The authors acknowledge Fundação de Amparo à Pesquisa do Estado de São Paulo (FAPESP), Conselho Nacional de Desenvolvimento Científico e Tecnológico (CNPq), and Coordenação de Aperfeiçoamento de Pessoal de Nível Superior (CAPES) (Brazilian research funding agencies) for their support of this work and the Microcopy Laboratory of FFCLRP, University of São Paulo.

\section{RESUMO}

Utilizou-se a metodologia sol-gel para obtenção de uma matriz de sílica modificada com íons de cálcio e fosfato. Preparou-se a matriz, por hidrólise e condensação dos precursores trietil fosfato, nitrato de cálcio, e tetraetilortosilicato, que foram as fontes de fosfato, de cálcio, e de silício, respectivamente. As amostras foram secas e tratadas termicamente a 110 e $900^{\circ} \mathrm{C}$ e colocadas em contato com fluido corporal simulado (SBF) por três dias. Realizou-se microscopia eletrônica de varredura, difração de raios $\mathrm{X}$, espectroscopia 
na região do infravermelho, o que evidenciou que a amostra tratada a $110^{\circ} \mathrm{C}$ continha silicato de cálcio, fosfato e hidroxiapatita, antes e após o contato com $\mathrm{SBF}$, respectivamente. A amostra tratada a $900^{\circ} \mathrm{C}$ exibiu a fase hidroxiapatita, antes e após o contato com SBF, mas a fase cristalina foi mais evidente após o contato. Em conclusão, o método de sol-gel forneceu amostras bioativas para regeneração óssea.

Palavras-chave: biomateriais, bioativo, SBF, metodologia sol-gel.

\section{REFERENCES}

ALONSO LM, Ferreira OJB, CARrodeguas RG AND Dos SANTOS LA. 2012. Bioactive composite bone cement based on alfa-tricalcium phosphate/tricalcium silicate. J Biomed Mater Res, Part B Applied Biomaterials 100B(1): 94-102.

ARcos D AND VALLET-Regí M. 2010. Sol-gel silica-based biomaterials and bone tissue regeneration Review Article. Acta Biomater 6(8): 2874-2888.

Bandeira lC, Ciuffi KJ, Calefi PS, Nassar EJ, Salvado IMM AND FERNANDES MHFV. 2011. Low temperature synthesis of bioactive materials. Cerâmica 57(342): 166-172.

BOSE S AND TARAFDER S. 2012. Calcium phosphate ceramic systems in growth factor and drug delivery for bone tissue engineering: A review. Acta Biomater 8(4): 1401-1421.

CAtel Y ET AL. 2012. Synthesis and evaluation of new phosphonic, bisphosphonic and difluoromethylphosphonic acid monomers for dental application. Eur Polym J 48: 318-330.

Chatzistavrou X, Esteve D, Hatzistavrou E, Kontonasaki E, PARASKEVOPOULOS KM AND BOCCACCINI AR. 2011. Sol-Gel Fabrication of Glass-Ceramic Composite Materials for Dental Application. Bioceramics Develop Appl 1: 1-4.

Chen F, Huang P, Zhu Y-J, Wu J, Zhang C-L and Cui D-X. 2011. The photoluminescence, drug delivery and imaging properties of multifunctional $\mathrm{Eu}^{3+} / \mathrm{Gd}^{3+}$ dual-doped hydroxyapatite nanorods. Biomaterials 32: 9031-9039.

GHosh SK, Roy SK, Kundu B, DATTA S AND BASU D. 2011. Synthesis of nano-sized hydroxyapatite powders through solution combustion route under different reaction conditions. Mater Sci Eng B 176: 14-21.

Guan X-H, Liu Q, Chen G-H and Shang C. 2005. Surface complexation of condensed phosphate to aluminum hydroxide: An ATR-FTIR spectroscopic investigation. J Coll Inter Sci 289: 319-327.

HeInemann S, Coradin T, Worch H, Wiesmann HP AND HANKE T. 2011. Possibilities and limitations of preparing silica/collagen/hydroxyapatite composite, xerogels as load-bearing biomaterials. Compos Sci Technol 71: 1873-1880.

Hong M-H, Son J-S, Kim K-M, Han M, OH DS AND LEE Y-K. 2011. Drug-loaded porous spherical hydroxyapatite granules for bone regeneration. J Mater Sci: Mater Med 22: 349-355.
Iafisco M, Varoni E, Di Foggia M, Pietronave S, Fini M, ROVERI N, RIMONDINI LAND PRAT M. 2012. Conjugation of hydroxyapatite nanocrystals with human immunoglobulin $\mathrm{G}$ for nanomedical applications. Colloids and Surfaces B: Biointerfaces 90: 1-7.

JADALANNAGARI S, MORE S, KowSHIK M AND RAMANAN SR. 2011. Low temperature synthesis of hydroxyapatite nanorods by a modified sol-gel technique. Mat Sci Eng C 31: 1534-1538.

KAWACHI EY, BERTRAN CA, Dos ReIS RR AND Alves OL. 2000. Biocerâmicas: Tendências e perspectivas de uma área interdisciplinar. Quím Nova 23(4): 518-522.

KIM SY AND JEON SH. 2012. Setting properties, mechanical strength and in vivo evaluation of calcium phosphatebased bone cements. J Ind Eng Chem 18: 128-136.

KoKUBO T. 1991. Bioactive glass ceramics: properties and applications. Biomaterials 12(1): 55-63.

LIM GK, WANG J, NG SC AND GAN LM. 1999. Nanosized hydroxyapatite powders from microemulsions and emulsions stabilised by a biodegradable surfactant. J Mater Chem 9: 1635.

LiU DM, YANG Q, Troczynski T AND TSEng W. 2002. Structural evolution of sol-gel derived hydroxyapatite. Biomaterials 23(7): 1679-1687.

Mohamed KR, El-Rashidy ZM AND SAlama AA. 2011. In vitro properties of nano-hydroxyapatite/chitosan biocomposites. Ceramics International 37: 3265-3271.

PARK E, CONDRATE RA AND LEE D. 1998. Infrared spectral investigation of plasma spray coated hydroxyapatite. Mater Lett 36: 38-43.

RADEV L, HRISTOVA K, JORDANAV V, FERNANDES MHV AND SALVADO IMM. 2012. In vitro bioactivity of $70 \mathrm{wt} . \% \mathrm{SiO}_{2}-$ $30 \mathrm{wt} . \% \mathrm{CaO}$ sol-gel glass, doped with 1,3 and $5 \mathrm{wt} . \% \mathrm{NbF}_{5}$. Cent Eur J Chem 10(1): 137-145.

RODRIQUEZ-ClEMENTE R, LOPEZ-MACIPE A, GOMEZ-MORALES J, TORRENT-BURGUES J AND CASTANO VM. 1998. Hydroxyapatite precipitation: a case of nucleation-aggregationagglomeration-growth mechanism. J Eur Ceramic Soc 18: 1351-1356.

SALIMI MN, BRIDSON RH, GROVER LM AND LEEKE GA. 2012. Effect of processing conditions on the formation of hydroxyapatite nanoparticles. Powder Technol 218: 109-118.

Sanchez C, Belleville P, Popall M and Nicole L. 2011. Applications of advanced hybrid organic-inorganic nanomaterials: from laboratory to market. Chem Soc Rev 40: 696-753.

SAnTos ML, Florentino AO, SAEKI MJ, APARECIDA AH, FoOK MVL AND GuAstaldi AC. 2005. Síntese de Hidroxiapatita pelo método sol-gel utilizando precursores alternativos: nitrato de cálcio e ácido fosforico. Eclética Quím 30(3): 29-35.

TABRIZI N, HONARMANDI P, EBRAHIMI-KAHRIZSANGI R AND HONARMANDI P. 2009. Synthesis of nanosize singlecrystal hydroxyapatite via mechanochemical method B. Mater Lett 63: 543-546. 
Tirapelli C, PAnzeri H, SoARes RG, Peitl O AND Zanotto ED. 2010. A novel bioactive glass-ceramic for treating dentin hypersensitivity. Braz Oral Res 24(4): 381-387.

Tofighi A. 2012. Calcium phosphate boné cement (CPBC): Development, commercialization and future challenges. Key Eng Mater 493-494: 349-354.

Trommer RM, Dos SANTOS LA AND Bergmann CP. 2007. Técnica alternativa para obter recobrimentos de hidroxiapatita. Cerâmica 53(326): 153-158.

VAllet-Regí M, COLILla Mand GONZÁleZAB. 2011. Medical applications of organic-inorganic hybrid materials within the field of silica-based bioceramics. Chem Soc Rev 40: 596-607.

WEI W, ZHANG X, CUI J AND WEI Z. 2011. Interaction between low molecular weight organic acids and hydroxyapatite with different degrees of crystallinity. Colloids and Surfaces A: Physicochem Eng Aspects 392: 67-75.
Yoshmura M, Suda H, OKMOtO K AND LOKU K. 1994. Hydrothermal synthesis of biocompatible whiskers. J Mater Sci 29: 3399.

Zamoume O, Thibault S, Regnié G, Mecherri MO, Fiallo M AND SHARROCK P. 2011. Macroporous calcium phosphate ceramic implants for sustained drug delivery. Mater Sci Eng C 31: 1352-1356.

Zhou Z, RuAN J, Zou J AND Zhou Z. 2008. Preparation and biactivity of sol-gel macroporous bioactive glass. J University Sci Technol Beijing 15(3): 290-296. 